\title{
The Process of Writing a Book about Baldwin's Self-Exile in Saint-Paul de Vence
}

\author{
Jules B. Farber
}

\begin{abstract}
Rather than write a classic biography of James Baldwin in the last cycle of his life-from his arrival in 1970 as a black stranger in the all-white medieval village of Saint-Paul, until his death there in 1987-I sought to discover the author through the eyes of people who knew him in this period. With this optic, I sought a wide variety of people who were in some way part of his life there: friends, lovers, barmen, writers, artists, taxi drivers, his doctors and others who retained memories of their encounters with Baldwin on all levels. Besides the many locals, contact was made with a number of Baldwin's further afield cultural figures including Maya Angelou, Harry Belafonte, Sidney Poitier, Angela Davis, Bill Wyman, and others. There were more than seventy interviews in person in places as distant as Paris, New York or Istanbul and by telephone spread over four years during the preparatory research and writing of the manuscript. Many of the recollections centred on "at home with Jimmy" or dining at his "Welcome Table."
\end{abstract}

Keywords: James Baldwin, Jimmy Baldwin, "Welcome Table," Mlle. Faure, Roux family, Saint-Paul de Vence, "Remember This House," I Am Not Your Negro

The concept for my book, James Baldwin: Escape from America, Exile in Provence, was formulated at La Colombe d'Or, an iconic hotel and restaurant in the fortified medieval village of Saint-Paul de Vence some twelve miles from Nice and the Mediterranean. While wandering in the narrow inner halls, a chance discovery of a photograph of James Baldwin caught my attention. When I returned to our table on the shady, walled-in terrace, I asked the waiter why there was a photo of Baldwin hanging so prominently. While arranging the many dishes of the establishment's renowned hors d'oeuvre, the waiter replied, "We all knew Jimmy, as we called him, like a member of the Roux family who own this place. They adopted him as one of them soon after he arrived and he was always en famille here."

James Baldwin Review, Volume 3, 2017 @ The Authors. Published by Manchester University Press and The University of Manchester Library 
How did Baldwin end up living in Saint-Paul? Life in the U.S. had become too much for him. He was haunted by the assassinations of black protest leaders, distressed by the setbacks in the Civil Rights movement and wounded by malicious FBI scrutiny. At the age of 46, he left the hostile atmosphere of America, returning to France to start on the third and final act of his literary career. But his wellbeing was short lived. He suffered from exhaustion and depression. Soon after he arrived in Paris, he collapsed and was placed in the American Hospital in Neuilly. When he reached the recuperation stage, friends shipped him off to Saint-Paul where he had some acquaintances from earlier visits.

I became interested in finding out from people who actually knew Baldwin in Saint-Paul about his lifestyle and integration in this all-white conservative enclave from 1970 to his death there in 1987. Curiously, Baldwin's literary work in this extended period rarely hinted at his French surroundings, though Just Above My Head (1978) contained brief descriptions of France. He felt American foremost, and could have been living in America reflecting on American themes and philosophy. Perhaps that is one of the compelling reasons why I became so enthusiastic about discovering Baldwin's last period when he remained a writer in self-exile like Henry James, his role model and literary mentor.

Who better to begin with than one of the three siblings of the present Roux clan: Michelle, called Pitou, the eldest, who supervises floral arrangements at the hotel. When I phoned her for an appointment, she suggested meeting in the hotel bar. I knew from many earlier visits to La Colombe d'Or that this bar was unlike those in most hotels with high stools and comfortable chairs, while here there were only cushions on a low bench. It's always surprising to see the hotel's elegant clientele, including celebrities, sitting so low.

Pitou arrived in an olive-colored Dior men's jacket worn over torn jeans topped off by a fashionable cloche. She was quick to explain the masculine attire:

Since he was a successful writer, his friends told him he should have expensive clothes and a big car so he bought some couturier clothes like this jacket and a Mercedes. Jimmy told me he wanted me to have this jacket after he passed. I sense being very close to him when I wear it.

Pitou had memories of Baldwin's visits that went back to the mid-1960s. She knew him longer and better than anyone else in town and remains dedicated to Baldwin with an almost mystical fervor. Baldwin was her protector and intimate counsellor for over two decades. As she recalled,

He was interested in me because I was young. He was curious about young people, what they thought, what they could teach him. Jimmy wanted to know all the racist jokes I heard-and he always reacted with great bursts of laughter. He would say things like, "I'm black, Jewish and homosexual—everything that's wrong."

Pitou told me how her mother and the actress Simone Signoret, who lived at the hotel for a good part of the year, finally convinced a racist older French landlady, 
Mlle. Faure, after much coercion, to rent an underground stable space, only accessible through a small, narrow passage under the kitchen in her big country house, to Baldwin to live in. The proprietor carried resentment of dark-skinned North Africans who had forced her departure from Algeria during the country's war of independence. She openly expressed anxiety about having a "neeger" under her roof and imposed her own personal form of apartheid, with a heavy wooden wardrobe blocking the inner door to her part of the stately seventeenth-century residence.

Where to start to develop lists of locals who had regular contacts with Baldwin? I struck gold when I approached Nicole Sobié of the Saint-Paul tourist office. Nicole appeared to know everyone in town who would have had any form of contact with Baldwin. And she continued to come up with people who had shared his daily routine there in one way or another: friends, lovers, barmen, doctors, secretaries, chauffeurs, mailmen, people on all levels with memories of their encounters. I ended up with over seventy interviews, mostly from in or near town, but also numerous far-reaching contacts all over the world. Everyone had great recollections of Baldwin in Saint-Paul-but I had to select.

My first local venture was a visit to Bertrand Mazodier, a native villager, at his antique jewellery boutique, La Balance. Bertrand told me,

In the early 1970s, when I was sixteen years old, I worked for the local post office. Since I was the only one who spoke English, I took down telegrams for Jimmy that came in by phone, letter by letter, every word spelled out, page after page. I generally ended up at his place just after twelve noon and got invited in for a glass or two of wine.

\section{Bertrand went on:}

I can't claim Jimmy was my friend. He was more like a grandmother to me, kissing me and I'm not gay. Initially, unfriendly natives were not happy to have him move in but it was not overt racism. Most of them are simple people who talk about their crops, vineyards, fruit trees, the weather-and they like to drink. Jimmy, with his openness, humor and disarming smile, quickly integrated into Saint-Paul life, admired and loved for the genuinely good person he was.

Bertrand pointed me a few doors down the village's main shopping street to the art gallery run by Heidi Widenfels, the statuesque blonde German woman who had been the chauffeur of Baldwin's Mercedes limousine. As Heidi told me during her interview,

I had first read his books in German, then later in English. You can't be friends if you don't know his books. I worked for him for three or four years. Life was easy with him, no stress. Many of his friends were dark. I was the only blonde. I think he liked having a big car driven by a big blonde. Wherever we went, people were curious at the sight. Sometimes we heard people say things like, "How can a nigger have a car like this?" When we were alone, his insecurity came out when he would lament: "I'm 
the ugliest one in the family_small and ugly—not the son of my father." He had a problem about being illegitimate.

Heidi suggested that I contact Marc Bosco, a taxi driver who loyally served Baldwin through the last decade of his life after a long-unpaid chauffeur disappeared with the Mercedes. Bosco, commenting on Baldwin's ongoing uneasiness concerning American politics, told me:

Jimmy was afraid of Reagan controls and feared going to the United States Consulate in Nice to get documents signed or to pick up papers. He was sure about the house being watched all the time, convinced he was always being followed and that his phone was bugged. He couldn't get what was happening in America off his mind.

Bosco's revelation led me to search for Peter Murphy who had been the Consul General of the United States in Nice from September 1975 through August 1977. I located Murphy living in Monaco. During our meeting he told me, "I remember that whenever Baldwin came to our office for notarial services, which was two or three times during the period I was posted there, he would always first ask for Sharon Hunt, Vice Consul, who is black."

Murphy went on,

\begin{abstract}
She was extremely nice and welcoming and I'm sure she put him at ease in our officehis only contact with the United States government abroad. They always chatted for a long time before he came to see me for the legalization of his signature on various documents. I'm sure Baldwin was convinced she was a spy assigned there to keep an eye on him.

Of course I knew who he was. I had read some of his books and recognized him as an important writer. I also knew his background in the United States, problems during the McCarthy era, the FBI surveillance under J. Edgar Hoover and personal attacks during his civil rights activities which finally led to his coming to France and settling not far from here. He always seemed uptight, jumpy, nervous at first but then we got into long conversations about music, and he relaxed.
\end{abstract}

Baldwin's schizophrenic bond with the U.S., which lasted virtually from the day he set foot in Saint-Paul until his passing, was usually mentioned during my contacts with many of the renowned American personalities who regularly visited the Baldwin household. Actually, Baldwin had reopened his early wounds shortly before his death in 1987 when he wrote thirty pages of a manuscript for a book entitled Remember This House as a witness recounting the lives and murders of three of his friends, Martin Luther King, Jr., Medgar Evers, and Malcolm X. Based on that text, the Haitian filmmaker Raoul Peck transformed James Baldwin's legacy onto the screen. Entitled I Am Not Your Negro, the film was nominated for a 2017 Oscar as a documentary feature.

Among those well-known Baldwin friends I contacted was the writer Maya Angelou. She confirmed that "The ambiance and climate of Saint-Paul gave 
Jimmy the opportunity to be more of an American than the climate offered in the United States. However, in his later years he often talked about his old remaining pain in the ongoing struggle for equality." Music producer and calypso singer Harry Belafonte told me,

As Americans we often discussed America. We each had our wounds from the past but Jimmy was particularly hurt, before and after he moved, by the criticism aimed at him both left and right. He talked like an expatriate living in France as contrasted to his living in the U.S. and how agonized he had been there, frustrated, angry, preoccupied by race problems and violence. Once in France, he felt he could deal with his life, celebrate his freedom, the newly found ease of his existence, a capacity to handle problems without someone breathing down your neck.

Notwithstanding his love-hate relationship, he prided himself on being an American and traveled there whenever required professionally or to earn muchneeded additional funds at universities, teaching annually for a semester. Despite always being short of funds, he lived and entertained lavishly the year round. Black jazz greats like Dizzy Gillespie, Julian "Canonball” Adderley, and Ray Charles never failed to stop by when they were playing the neighboring festivals. Miles Davis and Nina Simone stayed at the house, as did Toni Morrison with her young son for a week. Literary friends, mostly white, were regulars.

Far exceeding the cramped space in Baldwin's initial underground flat with an office he referred to as his "torture chamber," the country house had slowly become his kingdom, with an open door policy that attracted throngs of visitors of all types for lunch or dinner, or overnight accommodation for unspecified periods. This became possible since Mlle. Faure was amenable to Baldwin "buying" the rooms he needed for everyone invited, or not, to stay. The old spinster was charmed by Baldwin's elegant manner and wide, toothy smile. Her racism had evolved into a strange, loving friendship. She allowed him to continue "purchasing" rooms with the intention that one day the whole house would be his but, in fact, the transactions were generally agreements sealed with IOUs.

I went to Pierre Fuques, an attorney in neighboring Vence and Mlle. Faure's first cousin, for some explanation of this surprising situation. Fuques told me: "Jeanne was old and needed love, affection. As time went on, she told Jimmy he could live in the house as long as he wanted. She wanted him to have the housebut after he paid for it!" Hélène, the youngest Roux daughter, commented, “The most remarkable situation was Jimmy's relationship with Jeanne Faure. He was like a son and a lover to her. She totally adored him. She discarded all her rigid, opinionated bigotry to protect this black gay guy."

At one point Mlle. Faure allowed Baldwin to take possession of the main floor of the barn which had its own entrance at road level. Most significantly, from 1976 Baldwin was able to occupy the entire main house following an attempted break-in which caused the frightened, elderly woman to move to the village. 
During one of my frequent wanderings in the village I was advised not to miss the Dutch lady, Wanda van Dijk. Baldwin referred to her late husband Dick, who was coach for OGC Nice (Olympique Gymnaste Club Nice Côte d'Azur), as "my Dutch brother." They met at the bar of La Colombe d'Or on the anniversary of Martin Luther King, Jr.'s assassination and talked about the civil rights struggle and his essays about the confrontations that they read in his books.

"Discussing his work became our first bond," Wanda explained. "We didn't go into politics but very often he talked about racial problems. Jimmy was always Jimmy, fast to express his ideas. He made jokes about himself and about blacks and Jews. He believed in freedom and liberty everywhere, not just for the blacks." Wanda also recalled Baldwin's visits to their home. "Jimmy came often, whenever he wanted to just get away from too many people and noise at his place. He always felt he could relax here, sometimes not even talking. Often he would go into the garden and sing Negro spirituals." The contact clicked and they became close friends and regulars at "The Welcome Table."

"The Welcome Table" in the Baldwin household was a simple iron and glass table in the garden under the olive vines, as well as one inside. Its name was inspired by a verse from a Negro spiritual:

\section{One of These Days}

I'm going to sit at the Welcome Table

I'm going to feast on milk and honey

One of these days.

Dr. Roger Boizard, a general practitioner and close acquaintance, remembered,

At the table there was always an amusing mix of homosexuals and heterosexuals. Jimmy welcomed young dépenaillés, ragged types who arrived with empty pockets and valises full of problems-unknown artists, poets, musicians. Jimmy brought home guys from bars with no money. They just mixed in with the well-known black musicians and other personalities who were regulars.

A long-time friend and regular school vacation visitor, David Leeming-professor emeritus of English and comparative literature at the University of Connecticutwas a favorite at the table. During our luncheon meeting in Manhattan, David mentioned,

Most of all I remember sitting at the outdoor "Welcome Table." We would be there for hours talking about politics, race, religion, a diversity of subjects. Jimmy never looked at me as a white man. He was completely race-blind. He saw me for me. Jimmy was the only person I knew who could see through all the masks we wear.

To gain some further insight to "working for Jimmy," I sought, with great difficulty, Philippe Bébon, his last secretary. He had virtually disappeared after he left the household. Philippe explained, 
I had worked for Jimmy for four years but I had to leave. I couldn't take it anymore. It was intense, tiring, twenty-four hours a day. I had no private life. His sister Gloria, who was his secretary before me, told me she left because her hair started falling out. He was always nice, amiable, but ... his life pattern was so self-destructive that I couldn't bear to see him going on like that. I had to escape. I think I stayed the longest of any of the secretaries.

Curious about Baldwin's daily routine, I arranged a meeting at the Parisian café Flore with David Linx, a young Belgian musician who lived in the house for several years toward the end of Baldwin's life. David explained to me that

Jimmy would wake up late, having written all night, helped by a bottle of Scotch and a couple of packs of cigarettes. After lunch while Bernard, his "man Friday," and I rested on the bed he would read out loud to us what he had written the night before. He watched for reactions on our faces and asked for commentary.

Just as the "Welcome Table" was the central point of Baldwin's endless entertaining, he hoped until the end that the elegant, seventeenth-century residence would one day be developed into a haven for young artists and writers. Unfortunately, Baldwin's "purchases" were not recognized after his death, and a twenty-year legal battle ensued until 2007 among distant, so-called "family," who laid claim to the house. It was finally awarded to a cleaning woman who took care of Mlle. Faure when she lived in the village. She proved some long ago family connection on her father's side. The imposing structure and surrounding ten acres was sold in 2009 to a high-end land development corporation which in recent years has razed two wings. One of them was where Baldwin had worked and, at an earlier time, was used by the cubist painter Georges Braque as his atelier.

In late March 2017 as this is being written, battle continues over the future status of the house where James Baldwin had lived so happily. The Socri Group, owner of the estate, has municipal permission to construct eighteen luxury apartments starting in April. In the meantime, a Franco-American association of volunteers called His Place in Provence has launched an emergency fundraising effort for legal and community mobilization campaigns to block the bulldozers. However, work has been undertaken in the gatehouse on the road leading into the estate, to construct model apartments to stimulate advance buying. In the current situation Baldwin would probably have shrugged his shoulders and stoically accepted the loss of the house with an outward abandon. "Perhaps home is not a place but simply an irrevocable condition," he wrote in Giovanni's Room (1956). ${ }^{1}$ The only written reference and description of his residence published in his lifetime was the article "Architectural Digest Visits: James Baldwin, Text by James Baldwin," which appeared in that magazine's August 1987 issue, four months before died. He wrote,

A house is not a home: we have all heard the proverb. Yet, if the house is not a home (home!) it can become only, I suppose, a space to be manipulated-manipulation 
demanding rather more skill than grace. I have lived in many places, have been precipitated here and there. The beginning of my life rather recalls a shipwreck, and the shipwrecked can find it difficult to trust daylight or dry land ... Martin Luther King, Jr. was assassinated on April 4, 1968, while I was living in California. That devastated my universe and was ultimately to lead me to this house. ${ }^{2}$

\section{Notes}

1 James Baldwin, Giovanni's Room (London, Penguin, 1990), p. 88.

2 James Baldwin, "Architectural Digest Visits: James Baldwin, Text by James Baldwin," Architectural Digest (August 1987), p. 122.

\section{Works Cited}

Baldwin, James, Giovanni’s Room [1956] (London, Penguin, 1990).

“Architectural Digest Visits: James Baldwin, Text by James Baldwin,” Architectural Digest (August 1987).

\section{Contributor's Biography}

Jules B. Farber, an American author and journalist, graduated from Rutgers University with a Bachelor of Literary Letters in journalism. He held a diplomatic post as a State Department officer for the American Pavilion at the Brussels World's Fair in 1958. Subsequently he resided in Amsterdam for over thirty five years during which time he wrote freelance for various American and foreign publications and was awarded the prestigious Willem the Silent Prize by the Minister of Foreign Affairs for the best articles published in the American press about The Netherlands. Farber published four books in English and Dutch about Amsterdam and the country. Since moving to Provence, France, he has written three more books-all published in French and English, and one in German: Les Juifs du Pape en Provence, Itinéraires (2003) - also available as an English ebook-Classic Cats by Great Photographers (2005), and Talking About Cezanne (2006). His most recent book, James Baldwin: Escape from America, Exile in Provence (2016), is also available in ebook format. 